\title{
Hubungan Antara Proses Penyiapan Mp Asi dengan Kejadian Diare pada Bayi Usia 7-24 Bulan
}

\author{
Laurentina Dos Reis Lopesa, Sih Ageng Lumadia, Feriana Ira $\mathbf{H}^{\mathrm{a}}$ \\ ${ }^{a}$ STIKes Maharani Malang \\ E-mail: laurentine312@gmail.com
}

\begin{abstract}
Introduction:Diarrhea is a symptom with signs of changes in shape and consistency of liquid stools and frequency of defecation more than usual (3 times a day) throwing water five times a day and soft stools. Babies are said to be diarrhea if they have defecated more than three times a day, the effects of the disease are not only for the health of the baby, but also for the process of baby growth and development. This study aims to determine the relationship between the process of preparing complementary foods with the incidence of diarrhea in infants aged 7-24 months in Pandanlandung Village, Wagir District, Malang Regency. Method: The research method uses correlative descriptive with a case control approach. The sample in this study were 130 respondents, with simple random sampling technique. Results: From the chi square statistical test between the incidence of diarrhea with the preparation process of complementary foods ASI obtained $p$ value $=0,000(<a=0,05)$ with the value of $r$ +.456 so it can be concluded that there is a relationship between the incidence of diarrhea with the process of preparing complementary foods with the incidence of diarrhea in infants aged 7-24 months in Pandanlandung Village, Wagir District, Malang Regency. Conclusion: Means that the worse the process of preparing complementary foods, the higher the incidence of diarrhea. Suggestions from this study are expected respondents can find out the risk factors that can cause diarrhea, as well as the preparation process of MP ASI that is good for babies.
\end{abstract}

Keywords: Preparation of complementary foods for ASI, Diarrhea, infants aged 7-24 months

\begin{abstract}
Abstrak
Pendahuluan: Penyiapan MP ASI merupakan salah satu faktor yang mempengaruhi kejadian diare. Makanan yang tercemar, basi dan beracun, serta terlalu banyak lemak, mentah dan kurang matang biasanya memicu terjadinya diare pada bayi dan anak-anak. Diare pada bayi dapat disebabkan oleh beberapa hal seperti, lingkungan yang kumuh atau kurang baik, dan pemberian makanan yang kurang higienis. Penelitian ini bertujuan untuk mengetahui hubungan antara proses penyiapan makanan pendamping ASI dengan kejadian diare pada bayi usia 7-24 bulan di Desa Pandanlandung Kecamatan Wagir Kabupaten Malang. Metode: Metode penelitian menggunakan deskritif korelatif dengan pendekatan case control. Sampel pada penelitian ini sebanyak 130 responden,dengan teknik simple random sampling. Hasil: Dari uji statistik chi square antara kejadian diare dengan proses penyiapan makanan pendamping ASI didapatkan nilai $\mathrm{p}=0,000(<\mathrm{a}=0,05)$ dengan nilai $\mathrm{r} .456$ mempunyai arti arah hubungan variabel adalah positif serta kekuatan hubungan antar variabel dalam kategori sedang. Kesimpulan: sehingga dapat disimpulkan ada hubungan antara kejadian diare dengan proses penyiapan makanan pendamping ASI dengan kejadian diare pada bayi usia 7-24 bulan di Desa Pandanlandung Kecamatan Wagir Kabupaten Malang. Saran dari penelitian ini adalah
\end{abstract}


PROFESIONAL HEALTH JOURNAL

Volume 3, No. 1, Desember 2021 (Hal. 43-50)

https://www.ojsstikesbanyuwangi.com/index.php/PHJ

diharapkan responden dapat mengetahui faktor- faktor resiko yang dapat menyebabkan terjadinya diare, serta proses penyiapan MP ASI yang baik untuk bayi.

Kata kunci: Penyiapan makanan pendamping ASI, Kejadian Diare, Bayi usia 7-24 bulan.

\section{PENDAHULUAN}

Diare merupakan penyakit yang ditandai dengan buang air besar yang tidak normal dan bentuk tinja yang cair dengan frekuensi yang lebih banyak dari biasanya, bayi dikatakan diare bila sudah lebih dari tiga kali sehari buang air besar, dampak yang ditimbulkan dari penyakit tersebut bukan hanya bagi kesehatan bayi semata, melainkan juga bagi proses tumbuh kembang bayi (Mansjoer, 2009). Berbagai sebab diantaranya akibat pemberian susu formula yang tidak higienis dan MP ASI yang terlalu dini. (Halimah, Keperawatan, Tinggi, Kesehatan, \& Lampung, 2016)

Penyiapan MP ASI merupakan salah satu faktor yang mempengaruhi kejadian diare(Dewi Rani AP, 2015) (...) Makanan yang tercemar, basi dan beracun, serta terlalu banyak lemak, mentah dan kurang matang biasanya memicu terjadinya diare pada bayi dan anak-anak. Selain beberapa faktor tersebut, penularan diare biasanya terjadi melalui gelas, piring, atau sendok yang tidak bersih atau tercemar oleh kuman. Beberapa faktor perilaku juga mempengaruhi kejadian diare pada bayi dan anak-anak, misalnya perilaku tidak mencuci tangan dengan bersih sebelum dan sesudah makan, tidak memasak air yang akan diminum sampai mendidih, serta makanan yang habis masa kadaluarsanya dan terkontaminasi parasit (Depkes RI, 2008).

Berdasarkan informasi bidan di Desa Pandanlandung, bahwa setiap pemeriksaan kesehatan sebagian besar bayi terserang penyakit diare, dan setiap ditanyakan penyebab nya, sebagian besar ibu sudah menerapkan MP ASI kepada anak nya. Setiap bayi atau balita yang datang ke posyandu selalu diberi makanan pendamping asi seperti bubur susu, kolak kacang hijau dan biskuit. Pembuatan bubur susu dan kolak kacang hijau dibuat oleh ibu-ibu PKK sesuai dengan kebutuhan gizi yang dibutuhkan oleh balita, serta untuk tingkat kebersihan makanan nya belum kita ketahui dengan pasti. Menurut bidan di Desa Pandanlandung banyak balita yang mengalami muntah, konstipasi,diare dan gangguan menyusu, tetapi kejadian yang paling banyak terjadi adalah diare.

Saat ini morbiditas (angka kesakitan) bayi di Indonesia mencapai 195 per 1000 penduduk dan angka ini merupakan yang tertinggi di antara negara- negaradi Asean (Efradianto, 2014). Pada penelitian yang dilakukan oleh Rachman (2013) tentang hubungan pemberian susu formula dengan kejadian diare pada bayi usia 0-6 bulan di wilayah kerja puskesmas Kenali Besar didapatkan hasil bahwa sebanyak 36 bayi (75\%) mengalami diare.

Peneliti telah melakukan studi pendahuluan untuk mencari data banyaknya bayi yang terkena diare melalui hasil wawancara dengan bidan setempat dan melihat data kunjungan posyandu, serta menurut informasi dari bidan setempat, balita banyak terkena diare karena tingkat kebersihan makanan yang dibuat untuk MP ASI dan akan diberikan ke bayi kurang diperhatikan, tidak sesuai komposisi gizi. Peneliti mendapatkan data laporan dari Desa Pandanlandung Kecamatan Wagir Kabupaten Malang di RT 33- RT 37, terdapat 133 balita yang diberikan MP ASI. Oleh karena itu, berdasarkan latar belakang diatas, maka penulis tertarik untuk meneliti lebih jauh tentang hubungan antara proses penyiapan MP ASI pada anak usia 7-24 bulan dengan 
PROFESIONAL HEALTH JOURNAL

Volume 3, No. 1, Desember 2021 (Hal. 43-50)

https://www.ojsstikesbanyuwangi.com/index.php/PHJ

kejadian diare di Desa Pandanlandung Kecamatan Wagir Kabupaten Malang.

\section{METODE}

Jenis penelitian ini yaitu penelitian korelasional yaitu suatu penelitian yang mencoba mengkaji tingkat keterkaitan antara variasi suatu faktor dengan variasi faktor lain berdasarkan koefisien korelasi. Sedangkan metode penelitian ini menggunakan pendekatan case control dengan cara menentukan adanya penyakit diare atau tidak, kemudian menganalisis penyebab terjadinya penyakit diare. Penelitian ini dilakukan di Desa Pandanlandung, RT 33-37 Kecamatan Wagir Kabupaten Malang pada tanggal 27 Juli 2018 - 1 Agustus 2018.

Populasi dalam penelitian ini adalah ibuibu dan anak usia 7-24 bulan yang tercatat di wilayah Desa Pandanlandung. RT 33-37 Kecamatan Wagir Kabupaten Malang berjumlah 133 bayi. Teknik pengambilan sampel pada kelompok kasus (diare) dalam penelitian ini dilakukan dengan menggunakan simple random sampling, yaitu jenis pengambilan sampel probabilitas di mana setiap orang di seluruh populasi target memiliki kesempatan yang sama untuk dipilih. Sampel dipilih secara acak yang dimaksudkan sebagai representasi yang tidak bias dari total populasi. Jika karena alasan tertentu, sampel tidak mewakili populasi, variasi tersebut disebut kesalahan pengambilan sampel. Sampel acak memerlukan cara penamaan atau penomoran populasi target dan kemudian menggunakan beberapa jenis metode undian untuk memilih mereka yang akan dijadikan sampel Sampel dalam penelitian ini adalah ibu-ibu yang mempunyai anak usia 7-24 bulan dan tercatat diwilayah Desa Pandanlandung Kecamatan Wagir Kabupaten Malang, jadi sampel yang digunakan ada 100 bayi. Instrumen penelitian yang digunakan dalam penelitian ini mengadopsi dari penelitian sebelumnya, serta kuesioner yang terdiri dari kejadian diare, usia pemberian makanan pendamping ASI, jenis makanan pendamping ASI, serta perilaku kesehatan sebelum menyiapkan MP ASI. Uji statistik yang digunakan adalah uji chi square.

\section{HASIL}

Distribusi frekuensi responden berdasarkan kejadian diare pada bayi usia 7-24 bulan di Desa Pandan Landung Kecamatan Wagir Kabupaten Malang Berdasarkan data grafik 1 diketahui bahwa dari 32 responden didapatkan bahwa sebagian besar responden mengalami diare yaitu 82 responden $(82 \%)$

Tabel 1. Frekuensi Kejadian Diare

\begin{tabular}{cccccccc}
\hline & & \multicolumn{3}{c}{ Kejadian Diare } & \multicolumn{2}{c}{ Total } \\
& & \multicolumn{2}{c}{ Diare } & \multicolumn{2}{c}{ Tidak Diare } & \\
\hline \multirow{2}{*}{$\begin{array}{c}\text { Penyiapa } \\
\text { n MP }\end{array}$} & Buruk & 57 & 96.6 & 2 & 3.4 & 59 & 100 \\
ASI & Baik & 25 & 61 & 16 & 39 & 41 & 100 \\
& Total & 82 & 82 & 18 & 18 & 10 & 100 \\
& & & & & & 0 & \\
\end{tabular}

Distribusi frekuensi responden berdasarkan penyiapan MP ASI pada bayi usia 7-24 bulan di Desa Pandan Landung Kecamatan Wagir Kabupaten Malang.

Grafik 2. Proses Penyiapan MP ASI

\begin{tabular}{ccc}
\hline $\begin{array}{c}\text { Penyiapa } \\
\mathrm{n} \text { MP ASI }\end{array}$ & Frekuensi & $\begin{array}{c}\text { Persentase } \\
(\%)\end{array}$ \\
\hline Baik & 41 & 41 \\
Buruk & 59 & 59 \\
Total & 100 & 100 \\
\hline
\end{tabular}

Berdasarkan data grafik 2 diketahui bahwa dari 32 responden didapatkan bahwa sebagian besar responden memiliki proses penyiapan MP ASI yang buruk yaitu 59 responden $(59 \%)$.

Tabulasi silang proses penyiapan MP ASI dengan kejadian diare pada bayi 
PROFESIONAL HEALTH JOURNAL

Volume 3, No. 1, Desember 2021 (Hal. 43-50)

https://www.ojsstikesbanyuwangi.com/index.php/PHJ

usia 7-24 bulan di Desa Pandan Landung Kecamatan Wagir Kabupaten Malang

\begin{tabular}{cccccccc}
\hline & & \multicolumn{3}{c}{ Kejadian Diare } & \multicolumn{2}{c}{ Total } \\
\cline { 3 - 8 } & & & \multicolumn{9}{c}{ Diare } & \multicolumn{2}{c}{$\begin{array}{c}\text { Tidak } \\
\text { Diare }\end{array}$} \\
\hline \multirow{3}{*}{ Penyiapan } & Buruk & 57 & 96.6 & 2 & 3.4 & 59 & 100 \\
MP ASI & Baik & 25 & 61 & 16 & 39 & 41 & 100 \\
& Total & 82 & 82 & 18 & 18 & 100 & 100 \\
\hline
\end{tabular}

Grafik 3. Tabulasi Silang Proses Penyiapan MP ASI dengan Kejadian Diare

Berdasarkan grafik 3 dapat diketahui bahwa dari 100 responden hampir semuanya yang mengalami diare adalah responden yang proses penyiapan MP ASI yang buruk yaitu 57 responden $(96.6 \% \%)$ dan yang tidak mengalami diare sejumlah 2 responden. Dari uji statistik chi square antara kejadian diare dengan proses penyiapan makanan pendamping ASI didapatkan nilai $\mathrm{p}=0,000(<\mathrm{a}=0,05)$ dengan nilai $\mathrm{r} .456$

\section{PEMBAHASAN}

\section{A. Hubungan Penyiapan MP ASI Dengan Kejadian Diare}

Berdasarkan pada hasil analisis bahwa dari 100 responden didapatkan sebagian besar responden proses penyiapan MP ASI nya buruk yaitu 59 responden (59\%). Dari hasil penelitian diketahui bahwa 57 ibu bayi yang kurang baik dalam menyiapkan MP ASI untuk bayi mereka.

Pemberian makanan pendamping merupakan salah satu faktor yang mempengaruhi kejadian diare. Makanan yang tercemar, basi dan beracun, serta terlalu banyak lemak, mentah dan kurang matang biasanya memicu terjadinya diare pada bayi dan anak-anak. Selain beberapa faktor tersebut, penularan diare biasanya terjadi melalui gelas, piring, atau sendok yang tidak bersih atau tercemar oleh kuman. Beberapa faktor perilaku juga mempengaruhi kejadian diare pada bayi dan anakanak, misalnya perilaku tidak mencuci tangan dengan bersih sebelum dan sesudah makan, tidak memasak air yang akan diminum sampai mendidih, serta makanan yang habis masa kadaluarsanya dan terkontaminasi parasit. Penyakit diare biasanya mudah menular pada bayi dan anak-anak karena adanya penerapan pola hidup yang tidak benar dan pemberian makanan yang tidak sehat pada bayi dan anak-anak (Widjaja, 2002).

Daya tahan tubuh bayi masih sangat rentan, oleh karena itu makanan dan peralatan makan yang kurang bersih dapat membuat mereka mudah kemasukan kuman penyakit, yang dapat menyebabkan gangguan saluran cerna seperti diare (Sasongko, 2012).

Hasil penelitian ini didukung oleh penelitian Andriana (2010) tentang hubungan pemberian makanan pendamping ASI (MP-ASI) dengan kejadian diare pada bayi usia $>6$ bulan di Desa Koto Tinggi Wilayah Kerja Puskesmas Rambah, terdapat hubungan antara pemberian MPASI dengan kejadian diare dengan 
PROFESIONAL HEALTH JOURNAL

Volume 3, No. 1, Desember 2021 (Hal. 43-50)

https://www.ojsstikesbanyuwangi.com/index.php/PHJ

nilai $\mathrm{p}$ - value $=0,007$. Penelitian lain juga yang dilakukan oleh Sugeng Maryanto (2013) tentang hubungan pemberian MP-ASI dengan kejadian diare pada bayi umur 0-6 bulan di Desa Bancak Kabupaten Semarang, didapatkan nilai $\mathrm{p}$-value $=0,023$ yang berarti ada hubungan antara pemberian MP-ASI dengan kejadian diare.

Selanjutnya hasil penelitian Aditya Sasongko (2012) tentang hubungan pemberian MPASI dengan kejadian diare pada bayi umur 7-12 bulan di Kecamatan Pedan Kabupaten Klaten, didapatkan nilai pvalue $=0,020$ yang berarti ada hubungan antara pemberian MPASI dengan kejadian diare.

Hasil penelitian ini diketahui bahwa sebagian besar responden memiliki proses penyiapan MP ASI yang buruk dan hampir seluruhnya dari jumlah responden terkena diare. Kejadian diare pada bayi usia 7-24 bulan di Desa Pandanlandung Kecamawan Wair Kabupaten Malang ini disebabkan oleh beberapa hal. Tidak hanya dari cara ibu menyiapkan MP ASI saja, tidak menutup kemungkinan juga terjadi karena beberapa faktor seperti, kebersihan lingkungan sekitar serta kurang pengetahuannya ibu terhadap pemberian MP ASI yang baik untuk bayi.

Berdasarkan hasil penelitian dengan cara memberikan kuesioner maka diketahui tolak ukur untuk proses penyiapan MP ASI yang baik atau buruk. Dari hasil analisis diketahui sebagian besar responden tidak mengalami diare sejumlah 18 bayi (18\%) dan 82 responden (82\%) mengalami diare. Hal ini dikerenakan responden yang mengalami diare sering mengonsumsi makanan pendamping ASI yang kurang baik. Penyebab diare pada bayi, secara umum oleh dehidasi karena diare dan muntah yang berdampak pada hilangnya air dan garam tubuh.. Hal ini terjadi saat anak belajar mendapatkan MP-ASI. Makanan yang dimakan anak mungkin mengandung banyak kuman yang dapat menyebabkan infeksi usus dan anak terkena diare. Penyebab terjadinya diare seperti, pemberian makanan yang basi atau busuk seperti sering terjadi pada pemberian susu botol yang telah basi. Mengingat tingginya angka kematian akibat diare dan gizi buruk, maka penanganan penderita harus dilakukan dengan cermat (Setyorini, 2009).

Diare adalah suatu gejala dengan tanda-tanda adanya perubahan bentuk dan konsistensi tinja yang cair dan frekuensi buang air besar lebih dari biasanya (3 kali dalam sehari) buang air hingga lima kali sehari dan fesesnya lunak. bayi diyatakan diare bila frekuensi buang air besar sudah lebih dari 4 kali, sedangkan untuk bayi berumur lebih dari 1 bulan dan anak, bila frekuensi lebih dari 3 kali (Staf 
PROFESIONAL HEALTH JOURNAL

Volume 3, No. 1, Desember 2021 (Hal. 43-50)

https://www.ojsstikesbanyuwangi.com/index.php/PHJ

Pengejar Ilmu Kesehatan Anak,2000).

Dalam penelitian ini sejumlah 82 bayi yang mengalami diare. Diketahui pada saat studi pendahuluan dimana penelitian dilakukan, jumlah bayi yang mengalami diare sebanyak 5 orang. Maka dalam kurun waktu 2 bulan terdapat peningkatan jumlah bayi yang mengalami diare. Hal ini dimungkinkan selama kurun waktu 2 bulan terdapat konsumsi makanan pendamping ASI yang kurang baik sehingga menyebabkan gangguan pencernaan pada bayi.

Berdasarkan hasil hipotesis dengan uji spearman didapatkan nilai $p$ sebesar 0,000 . Nilai signifikasi tersebut lebih kecil dari $\alpha=0,05$. Dari pengujian ini didapatkan kesimpulan bahwa ada hubungan proses penyiapan MP ASI dengan kejadian diare pada bayi usia 7-24 bulan di Desa Pandanlandung Kecamatan Wagir Kabupaten Malang. Peneliti meneliti 82 responden mengalami diare dan 18 responden tidak mengalami diare, dimana terdapat penyiapan MP ASInya baik, akan tetapi masih terjadi diare sebanyak 25 responden. Hasil penelitian ini tanda koefisien adalah positif, dengan nilai koefisien +0.456 artinya hubungan proses penyiapan MP ASI dengan kejadian diare pada bayi usia 7-24 bulan di Desa Pandanlandung Kecamatan Wagir Kabupaten Malang adalah berbanding lurus dimana antara

variabel bebas dan variable terikatnya hubungannya sedang. Dengan koefisien korelasi juga dapat ditentukan kekuatan korelasi (r) yang menginterprestasikan seberapa kuat hubungan yang ditimbulkan antara 2 variabel penelitian. Hasil penelitian ini diketahui pada rentang sedang yakni 0.456 (rentang 0.40-0.599).

Seringnya mengkonsumsi makanan cepat saji dan jarang berolahraga, akan mengalami penambahan berat badan yang tidak sehat. Hasil lemak dari mengkonsumsi makanan cepat saji tidak digunakan dengan baik oleh tubuh sehingga lemak inilah yang kemudian tersimpan dan menumpuk yang kemudian mengakibatkan obesitas (Fendi, 2013).

MP ASI merupakan makanan peralihan dari ASI ke makanan keluarga. Pengenalan dan pemberian MP ASI harus dilakukan secara bertahap baik bentuk maupun jumlah. Hal ini dimaksudkan untuk menyesuaikan kemampuan alat pencernaan bayi dalam menerima MP ASI (Sasongko, 2012). MP ASI merupakan peralihan asupan yang semata berbasis susu menuju ke makanan yang semi padat. Untuk proses ini juga dibutuhkan ketrampilan motorik oral. Ketrampilan motorik oral berkembang dari refleks menghisap menjadi menelan makanan yang berbentuk bukan cairan dengan memindahkan makanan dari lidah 
PROFESIONAL HEALTH JOURNAL

Volume 3, No. 1, Desember 2021 (Hal. 43-50)

https://www.ojsstikesbanyuwangi.com/index.php/PHJ

bagian depan ke lidah bagian belakang (Agustin, 2015).

Menurut Irianto dan

sebanyak 82 responden $(82 \%)$.

3. Ada hubungan antara proses penyiapan makanan Waluyo (2004) dalam pemberian MP ASI yang dikonsumsi hendaknya memenuhi kriteria bahwa makanan tersebut layak untuk dimakan dan tidak menimbulkan penyakit, serta makanan tersebut sehat, diantaranya : harus dalam derajat kematangan, bebas dari pencemaran dan menyajikan hingga menyuapi pada bayi atau anak, bebas dari perubahan fisik, kimia yang tidak dikehendaki, sebagai akibat dari pengaruh enzim, aktifitas mikroba, hewan pengerat, serangga. bebas dari mikroorganisme dan parasit yang menimbulkan penyakit yang dihantarkan oleh makanan (food borne illness), harus cukup mengandung kalori dan vitamin, serta yang paling penting adalah mudah dicerna oleh alat pencernaan

\section{KESIMPULAN DAN SARAN}

\section{Kesimpulan}

Berdasarkan pada hasil analisis dapat diambil beberapa kesimpulan sebagai berikut:

1. Proses penyiapan makanan pendamping ASI pada bayi usia 7-24 bulan di Desa Pandanlandung Kecamatan Wagir Kabupaten Malang sebagian besar adalah buruk yaitu 59 responden (59\%).

2. Kejadian diare pada bayi usia 7-24 bulan di Desa Pandanlandung Kecamatan Wagir Kabupaten Malang

\section{Saran} pendamping ASI dengan kejadian diare di Desa Pandanlandung Kecamatan Wagir Kabupaten Malang.

1. Bagi Responden

Diharapkan dengan adanya penelitian ini ibu yang mempunyai bayi usia 7-24 bulan dapat mengetahui proses penyiapan MP ASI yang baik untuk bayi.

2. Bagi Tempat Penelitian

Dengan didapatkannya hasil penelitian di harapkan Desa Pandanlandung Kecamatan Wagir Kabupaten Malang dapat memberikan pengetahuan dan penyuluhan pada ibu- ibu yang memiliki bayi usia 7-24 bulan tentang penyiapan Makanan Pendamping ASI yang baik dan layak untuk dikonsumsi bayi .

3. Bagi Peneliti Selanjutnya

Diharapkan pada penelitian selanjutnya yang tertarik dalam penelitian ini, dapat melengkapi beberapa hal yang belum dibahas oleh peneliti saait ini, yaitu faktorfaktor lain yang dapat mempengaruhi terjadinya diare, selain faktor penyiapan makanan pendamping ASI, antara lain faktor lingkungan sekitar, faktor perilaku kesehatan yang kurang diperhatikan, serta faktor pemberian makanan pendamping ASI yang terlalu dini dengan menggunakan metode penelitian kohort.

\section{DAFTAR PUSTAKA}


PROFESIONAL HEALTH JOURNAL

Volume 3, No. 1, Desember 2021 (Hal. 43-50)

https://www.ojsstikesbanyuwangi.com/index.php/PHJ

Agustina,Dewi. 2015. Hubungan Pemberian Jenis Makan Pendamping Asi Dini Dengan Motilitas Usus Pada Bayi Usia 0-6 Bulan

Cahyaningrum. 2015. Studi Tentang Diare Dan Faktor Resikonya Pada Balita Umur 1-5 Tahun Di Wilayah Kerja Puskesmas Kalasan Sleman Naskah.

Damayanti. 2011. Buku Ajar Nutrisi Pediatrik dan Penyakit Metabolik. Jakarta. Badan Penerbit IDAI.

Depkes RI. 2007. Buku Pedoman Pemberian Makanan Pendamping ASI. Jakarta: Ditjen Bina Kesehatan Masyarakat dan Direktorat Bina Gizi Masyarakat

Gibney MJ, Margetts BM, Kearney JM, Arab L. Gizi Kesehatan Masyarakat. Jakarta: EGC; 2008.

Dewi Rani AP, S. (2015). HUBUNGAN PEMBERIAN JENIS MAKAN PENDAMPING ASI DINI DENGAN MOTILITAS USUS PADA BAYI USIA 0-6 BULAN, 2(4), 0-6.

Fendi, W. (2013). Kimia Pangan Dan Gizi. Jakarta: Gramedia Pustaka Utama.

Halimah, R., Keperawatan, P. S., Tinggi, S., Kesehatan, I., \& Lampung, M. (2016). HUBUNGAN MAKANAN PENDAMPING AIR SUSU IBU ( MP-ASI ) DENGAN KEJADIAN DIARE PADA ANAK BAYI, 360365.

Sasongko, A. (2012). HUBUNGAN ANTARA PEMBERIAN MP-ASI DENGAN DI KECAMATAN PEDAN KABUPATEN. 